\title{
CHANGES IN RENAL FUNCTION ACCOMPANYING THE HYPERTROPHY OF THE REMAINING KIDNEY AFTER UNILATERAL NEPHRECTOMY ${ }^{1}$
}

\author{
By CATHERINE A. WELSH, IRWIN WELLEN, AND HOWARD C. TAYLOR, JR., \\ WITH THE TECHNICAL ASSISTANCE OF ANNA ROSENTHAL \\ (From the Department of Obstetrics and Gymecology, New York University College of Medicine, and \\ the Obstetrical and Gynecological Service of the Third (New York University) Surgical \\ Division of Bellevue Hospital, New York City)
}

(Received for publication February 24, 1944)

The functional changes which accompany the hypertrophy of the kidney remaining after unilateral nephrectomy have been followed by the measurement of the glomerular filtration rate, effective renal blood flow, and tubular excretory mass. Such observations may serve to demonstrate the mechanism by which hypertrophy is accomplished.

That hypertrophy of the remaining kidney after unilateral nephrectomy occurs, and that this hypertrophy is not accomplished by the formation of new nephrons, have been demonstrated repeatedly ( 1 to 6 ). It has been suggested that this organ growth is a work hypertrophy, a response to functional demands. This view is supported by the fact that the degree of growth is greater on high than on low protein diets, and by the fact that the larger the proportion of total renal substance resected, the greater is the relative hypertrophy (6 to 12).

Changes in renal function, comparable to the increase in kidney weight, have not previously been demonstrated. However, the great increase in diodrast $\mathrm{Tm}$ in the dog following the administration of testosterone propionate (13), a substance known to increase kidney weight in rats and mice (14 to 17 ), certainly suggests that renal hypertrophy is accompanied by an increase in diodrast $\mathrm{Tm}$. The increase in diodrast $\mathrm{Tm}$ in the dog following the administration of testosterone propionate may be as much as 100 per cent (13). A very much smaller increase in diodrast $\mathrm{Tm}$ in man has been shown when testosterone propionate was administered soon after unilateral nephrectomy, and no increase when given to men with both kidneys present (18).

\footnotetext{
1 This study was made with the aid of a grant from the Commonwealth Fund.
}

The present communication reports the observations on renal function, made after unilateral nephrectomy performed during the pregnancies of 2 women. Studies were made within a few weeks of the operation and were repeated at intervals until 14 and 40 months had elapsed, respectively. Renal function was measured by the clearance method. The clearance of inulin or mannitol has been shown to be a measure of the rate of glomerular filtration; the diodrast clearance, of the amount of blood supplying excretory tissue. The diodrast Tm is an expression of the maximal capacity of the tubules to excrete diodrast and it has therefore been considered a measure of total functioning tubular tissue $(19,20)$. The methods of performing the tests were described in a previous report (21). The normal control group with which these subjects with a single kidney are compared consists of 14 non-pregnant women $(22,23)$, and 8 pregnant women (21). The average figures for the control group are: inulin clearance $122 \mathrm{ml}$. per minute, diodrast clearance $613 \mathrm{ml}$. per minute; diodrast Tm $43.7 \mathrm{mgm}$. iodine per minute, filtration fraction 19.9 per cent, $C_{D} / T_{m}$ ratio 14.0 , and $\mathrm{C}_{\mathrm{IN}} / \mathrm{Tm}_{\mathrm{D}}$ ratio 2.79 .

\section{CASE HISTORIES}

The histories of the 2 patients are to be contrasted in one respect in particular. In the first patient, the removed kidney was apparently a functioning organ at the time of the nephrectomy, while in the second, the kidney had already undergone almost complete destruction as a result of a malignant tumor.

1. E. M. was a 29-year-old colored female whose left kidney was removed at the sixth month of her pregnancy. This patient had suffered for 3 years from painless hematuria and repeated cystoscopic examinations had shown bleeding from the left ureteral orifice. The only renal function test before operation was the timed appearance of 
methylene blue from the 2 ureters, which was found to be normal.

Recovery from the operation was uneventful and pregnancy proceded normally until the ninth month. At that time, she rather suddenly developed specific toxemia with hypertension, proteinuria, convulsions, and coma and was delivered of a dead fetus at another hospital. Following delivery, the blood pressure reached normal on the eighth post-partum day, but 1 month after delivery was again high. The blood pressure, next taken 2 months after delivery, was normal and has remained so at each of the frequent observations in the last 3 years.

The pathological findings in the kidney removed at operation have been reported in detail (24). Multiple hemorrhagic erosions of the pelvis and ureter were present to explain the persistent bleeding. In addition, there were massive medial hypertrophy and hyperplasia of the arterioles, a finding most prominent on the afferent side of the glomerulus. The architecture of the kidney was well preserved, the glomeruli and tubules themselves appearing normal.

2. M. C. was a 40-year-old white female whose right kidney was removed in the fourth month of her sixth pregnancy. Recovery from the operation was uncomplicated. The patient was delivered at term of a normal infant.

Pathologic examination of the removed kidney disclosed practically no normal renal parenchyma, all having been replaced by adenocarcinoma. The patient has recently been examined and there has been to date no evidence of any recurrence.

\section{RESULTS}

The functional compensations which develop after nephrectomy may be followed by noting the changes in the clearance measurements which are given in detail in Table $I$. The essential points to be noted are as follows:

\section{Effect of removal of a functioning kidney (Case E. M.)}

Sixteen days after nephrectomy. At the time of these measurements, the patient was beginning the seventh month of her pregnancy and had clinically recovered from her operation. The diodrast $\mathrm{Tm}$ was one-half the average normal value, the clearances of inulin and diodrast about three-fourths the normal value. The ratios of the glomerular filtration rate and of effective plasma flow to the tubular excretory mass $\left(\mathrm{C}_{\mathrm{IN}} / \mathrm{Tm}_{\mathrm{D}}\right.$ and $\left.\mathrm{C}_{\mathrm{D}} / \mathrm{Tm}_{\mathrm{D}}\right)$ were therefore relatively high. The figure of 19.3 for the $C_{D} / T_{m}$ ratio is above the normal mean by more than 3 times the standard deviation of this figure in the control group and demonstrates the presence of hyperemia in the remaining kidney.

Four months after nephrectomy. At this time, the patient was 1 month post-partum after a pregnancy complicated by specific toxemia and her blood pressure was still elevated. All postpartum patients with residual hypertension after toxemia in our experience (25) have shown a tendency to renal ischemia.

In the present case, the diodrast $\mathrm{Tm}$ was found but little higher than the level noted immediately

TABLE I

Renal clearances following the removal of a functioning and a non-functioning kidney

\begin{tabular}{|c|c|c|c|c|c|c|c|c|c|c|c|c|c|c|c|}
\hline \multirow{2}{*}{$\underset{\text { ject }}{\text { Sub- }}$} & \multirow{2}{*}{ Date } & \multirow{2}{*}{$\begin{array}{l}\text { Time } \\
\text { before } \\
\text { or after } \\
\text { delivery }\end{array}$} & \multirow{2}{*}{$\begin{array}{c}\text { Time } \\
\text { after } \\
\text { nephrec- } \\
\text { tomy }\end{array}$} & \multirow{2}{*}{$\begin{array}{l}\text { Blood } \\
\text { pres- } \\
\text { sure } \\
\text { during } \\
\text { test }\end{array}$} & \multirow{2}{*}{$\begin{array}{c}\text { Dio- } \\
\text { drast } \\
\text { Tm }\end{array}$} & \multicolumn{3}{|c|}{ Plasma clearances } & \multirow{2}{*}{$\begin{array}{l}\text { Effec- } \\
\text { tive } \\
\text { renal } \\
\text { blood } \\
\text { flow }\end{array}$} & \multirow{2}{*}{$\begin{array}{l}\text { Inulin/ } \\
\text { Phenol } \\
\text { red }\end{array}$} & \multirow{2}{*}{\begin{tabular}{|}
$\begin{array}{c}\text { Filtra- } \\
\text { tion } \\
\text { fraction }\end{array}$ \\
$\begin{array}{c}\text { Inulin/ } \\
\text { Dio- } \\
\text { drast }\end{array}$ \\
\end{tabular}} & \multirow{2}{*}{$\begin{array}{l}\text { Phenol } \\
\text { red } \\
\text { Dio- } \\
\text { drast }\end{array}$} & \multirow{2}{*}{$\begin{array}{c}\text { Effec- } \\
\text { tive } \\
\text { renal } \\
\text { blood } \\
\text { flow/ } \\
\text { Tmp }\end{array}$} & \multirow{2}{*}{$\underset{T m_{D}}{C}$} & \multirow{2}{*}{$\mid \begin{array}{c}\mathbf{C}_{\text {Is }} / \\
\operatorname{Tm}_{\mathbf{D}}\end{array}$} \\
\hline & & & & & & Inulin & $\begin{array}{c}\text { Phenol } \\
\text { red }\end{array}$ & $\begin{array}{l}\text { Dio- } \\
\text { drast }\end{array}$ & & & & & & & \\
\hline & & & & & $\begin{array}{l}\text { mgm. } \\
\text { iodine. } \\
\text { per } \\
\text { minute }\end{array}$ & \multicolumn{3}{|c|}{ ml. per 1.73 sq. $m}$. & $\begin{array}{l}\text { ml. per } \\
1.73 \\
\text { sq. m. } \\
\text { per } \\
\text { minute }\end{array}$ & $\begin{array}{l}\text { per } \\
\text { cent }\end{array}$ & $\begin{array}{l}\text { per } \\
\text { cent }\end{array}$ & $\begin{array}{l}\text { per } \\
\text { cent }\end{array}$ & & & \\
\hline E. M. & $\begin{array}{l}\text { March 11, } 1940 \\
\text { June 26, } 1940 \\
\text { October 2, } 1940 \\
\text { February 27, } 1941 \\
\text { October 28, 1941 } \\
\text { September 23, } 1942 \\
\text { July 26, } 1943\end{array}$ & $\begin{array}{l}\text { A } 3 \text { mos. } \\
\text { P } 1 \text { mo. }\end{array}$ & 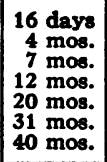 & $\begin{array}{l}120 / 70 \\
162 / 100 \\
118 / 78 \\
120 / 70 \\
110 / 70 \\
134 / 84 \\
120 / 80\end{array}$ & $\begin{array}{l}23.2 \\
26.0 \\
25.8 \\
33.3 \\
42.6 \\
34.2 \\
33.6\end{array}$ & $\begin{array}{l}92 . \\
73 . \\
98 . \\
79 . \\
73 . \mathrm{m} \\
\text { 81. } \\
79 . \mathrm{m}\end{array}$ & $\begin{array}{l}246 \\
202 \\
259 \\
272 \\
260 \\
263 \\
219\end{array}$ & $\begin{array}{l}446 \\
278 \\
423 \\
564 \\
565 \\
600 \\
440\end{array}$ & $\begin{array}{r}718 \\
465 \\
745 \\
1040 \\
1017 \\
952 \\
697 \\
\end{array}$ & $\begin{array}{l}37.4 \\
36.4 \\
37.8 \\
29.0 \\
28.1 \\
30.8 \\
36.0\end{array}$ & $\begin{array}{l}20.6 \\
26.3 \\
23.2 \\
14.0 \\
12.9 \\
13.5 \\
18.0\end{array}$ & $\begin{array}{l}55.2 \\
72.6 \\
61.2 \\
48.2 \\
46.0 \\
43.8 \\
49.8\end{array}$ & $\begin{array}{l}31.0 \\
17.9 \\
28.9 \\
31.2 \\
23.9 \\
27.8 \\
20.7\end{array}$ & $\begin{array}{l}19.2 \\
10.7 \\
16.4 \\
16.9 \\
13.3 \\
17.5 \\
13.1\end{array}$ & $\begin{array}{l}3.97 \\
2.81 \\
3.80 \\
2.37 \\
1.71 \\
2.37 \\
2.35\end{array}$ \\
\hline$\overline{\text { M. C. }}$ & $\begin{array}{l}\text { November } 17,1941 \\
\text { January } 7,1942 \\
\text { February } 2,1942 \\
\text { May } 21,1942 \\
\text { November } 18,1942\end{array}$ & $\begin{array}{l}\text { A } 2 \text { mos. } \\
\text { A } 3 \text { whes. } \\
\text { P } 6 \text { days }\end{array}$ & $\begin{array}{r}2 \text { mos. } \\
4 \text { mos. } \\
5 \text { mos. } \\
8 \text { mos. } \\
14 \text { mos. }\end{array}$ & $\begin{array}{l}140 / 86 \\
134 / 90 \\
136 / 88 \\
120 / 80 \\
110 / 70\end{array}$ & $\begin{array}{l}34.4 \\
31.2 \\
39.3 \\
36.9 \\
34.5\end{array}$ & $\begin{array}{l}70.0^{\mathrm{m}} \\
69.0^{\mathrm{m}} \\
74.0^{\mathrm{m}} \\
62.0^{\mathrm{m}} \\
65.0^{\mathrm{m}}\end{array}$ & $\begin{array}{l}261 \\
216 \\
211 \\
221 \\
187\end{array}$ & $\begin{array}{l}344 \\
371 \\
451 \\
483 \\
340\end{array}$ & $\begin{array}{l}525 \\
533 \\
678 \\
737 \\
536\end{array}$ & $\begin{array}{l}26.8 \\
32.0 \\
35.1 \\
28.1 \\
34.8\end{array}$ & $\begin{array}{l}20.3 \\
18.6 \\
16.4 \\
12.8 \\
19.1\end{array}$ & $\begin{array}{l}75.9 \\
58.2 \\
46.8 \\
45.8 \\
55.0\end{array}$ & $\begin{array}{l}15.3 \\
17.1 \\
17.3 \\
20.0 \\
15.5\end{array}$ & $\begin{array}{l}10.0 \\
11.9 \\
11.5 \\
13.1 \\
9.86\end{array}$ & $\begin{array}{l}2.03 \\
2.21 \\
1.88 \\
1.68 \\
1.88\end{array}$ \\
\hline
\end{tabular}

$m$ Mannitol clearance. Since the mannitol clearance is identical to the inulin clearance, inulin only is used in the headings. 
after nephrectomy. The diodrast clearance was diminished and the filtration fraction correspondingly increased to the levels believed to be characteristic of efferent arteriolar hypertonus (26). The functional changes associated with the post-toxemic hypertension appear at the time of this test to overshadow those due to the compensatory alterations in the kidney remaining after nephrectomy.

Seven months after nephrectomy. At this time, the patient had ceased to show any sequellae from the eclampsia and her blood pressure was normal. The results at this time were almost identical with those found in the first test. The diodrast clearance had risen to the level seen before the advent of toxemia and renal hyperemia was again evident.

Twelve months after nephrectomy. At the end of 1 year, the diodrast $\mathrm{Tm}$ had increased from the original figure of 53 per cent to 76 per cent of normal. The diodrast clearance had continued to increase, so that renal hyperemia was evidently still present. The inulin clearance on the other hand had decreased slightly and the filtration fraction had fallen to the lower limits of normal.

Twenty months after nephrectomy. The diodrast $\mathrm{Tm}$ for the remaining kidney had now increased still further and was found only 3 per cent below the average normal figure for 2 kidneys. This figure is within the normal range and the compensatory hypertrophy may thus be thought of as complete. The diodrast clearance had previously reached correspondingly high levels and the blood flow to the excretory tissue was therefore now normal. With the exception of the low rate of filtration at the glomerulus, the 1 kidney was now doing the amount of work normally done by 2 kidneys.

Thirty-one months after nephrectomy. In this observation, a fall in diodrast Tm was noted, with no change in glomerular filtration rate or effective renal blood flow.

Forty months after nephrectomy. The diodrast Tm showed no further change. The effective renal blood flow was lower than that shown by any observation from the twelfth through the thirty-first month after operation, indicating that hyperemia was no longer present. How- ever, the blood flow per unit of excretory tissue and the filtration fraction were normal.

\section{Effect of removal of a non-functioning kidney}

(Case M. C.)

At the time of the first test, made 2 months after nephrectomy, the patient was in the eighth month of a normal pregnancy. Observations made at this time showed the diodrast $\mathrm{Tm}$ to be about three-quarters of the normal average while the inulin and diodrast clearances were little more than half the normal.

In subsequent measurements, at $4,5,8$, and 14 months after nephrectomy, the diodrast Tm showed no progressive change. The diodrast clearance exhibited a slight but consistent increase through the eighth month. The inulin clearance, however, remained low, but without significant differences, in the 5 tests. The ratio of glomerular filtration rate to tubular excretory mass $\left(C_{I N} / T_{D}\right)$ was low in all of the observations, and that of the effective plasma flow to the tubular excretory mass $\left(\mathrm{C}_{\mathrm{D}} / \mathrm{Tm}_{\mathrm{D}}\right)$ low except in the one carried out in the eighth month after operation. At no time then was there evidence of the renal hyperemia noted in the first case.

\section{DISCUSSION}

There is little reason to suppose that pregnancy had any special bearing on the changes observed following nephrectomy in either case. Normal pregnancy has no effect on the renal function measurements that were used here (21), and at the time of the earliest observations on each case, both women, though pregnant, were normal. In the first patient, a transitory episode of hypertension following eclampsia was accompanied by a temporary reduction in the renal blood flow. In all other tests subsequent to the pregnancies of both women, there were no signs or symptoms of vascular or renal disease.

The results obtained in the study of the 2 patients offer a marked contrast which is to be explained on the basis of the functional capacity of the kidney removed.

After the loss of an active kidney, the functional changes which occur are probably as follows: The tubular excretory mass must at once be cut in half as a result of the anatomical re- 
moval of half of the renal tissue of the body. The glomerular filtration rate and effective renal blood flow are, momentarily at least, reduced to a similar extent. Very soon, however, as a result of functional changes, the glomerular filtration rate and the effective renal blood flow increase considerably.

The early increase in glomerular filtration rate is apparently the maximal expansion of this function under these conditions but the effective blood flow continues to increase for several months. This may be accomplished, in part at least, by efferent arteriolar dilatation which would result in a lowered intraglomerular pressure and thus account for a decreased filtration rate.

The tubular excretory mass does not increase at first as rapidly as does the effective renal blood flow and during this early period, there is a relative hyperemia of the renal excretory tissue. This hyperemia persists until the time when the compensatory hypertrophy of the tubular excretory tissue has been accomplished. In the first case studied, the completion of this process apparently required nearly 2 years.

The observable effects of the loss of a nonfunctioning kidney are quite different, since the early changes must necessarily have taken place some time before nephrectomy. The kidney removed at operation in the second of our patients contained, as noted, no normal renal tissue. The figure for the tubular excretory mass 2 months after operation was already three-fourths of the average for 2 normal kidneys, a value which was not reached by the first patient until a year after her operation. Renal hyperemia was furthermore not evident in any of the observations made on the second case, despite the slight rise in effective blood flow notable through the eighth month.

\section{CONCLUSIONS}

1. The functional changes accompanying the renal hypertrophy which follows unilateral nephrectomy have been studied in 2 patients.

2. Following the removal of a previously functioning kidney, there was evidence of a rapid rise in glomerular filtration rate and effective renal blood flow and a much delayed increase in the mass of functioning tubular tissue (diodrast
$\mathrm{Tm})$. The increase in diodrast Tm apparently parallels the morphologic hypertrophy of the kidney.

3. Following the removal of a kidney previously destroyed by disease, these changes were not noted. The high figure for the diodrast $\mathrm{Tm}$ demonstrated, however, that a similar hypertrophy must have occurred previous to operation in this case.

\section{BIBLIOGRAPHY}

1. Arataki, M., Compensatory enlargement of the surviving kidney after unilateral nephrectomy. Am. J. Anat., 1926, 36, 437.

2. Shiels, M. A., Effect of unilateral nephrectomy upon number of renal corpuscles in young albino rats. Proc. Soc. Exper. Biol. and Med., 1927, 24, 916.

3. Jackson, C. M., and Shiels, M., Compensatory hypertrophy of kidney during various periods after unilateral nephrectomy in young albino rats. Anat. Rec., 1927, 36, 221.

4. Saphir, O., State of the glomerulus in experimental hypertrophy of kidneys in rabbits. Am. J. Path., 1927, 3, 329.

5. Moore, R. A., Number of glomeruli in kidney of adult white rat unilaterally nephrectomized in early life. J. Exper. Med., 1929, 50, 709.

6. Allen, R. B., and Mann, F. C., Experiments on compensatory renal hypertrophy. Arch. Path., 1935, $19,341$.

7. Smith, A. H., and Moise, T. S., Diet and tissue growth; rate of compensatory renal enlargement after unilateral nephrectomy in white rat. J. Exper. Med., 1927, 45, 263.

8. MacKay, E. M., MacKay, L. L., and Addis, T., Factors which determine renal weight. V. The protein intake. Am. J. Physiol., 1928, 86, 459.

9. Chanutin, A., and Ludewig, S., Experimental renal insufficiency produced by partial nephrectomy; diets containing whole dried meat. Arch. Int. Med., 1936, 58, 60.

10. MacKay, L. L., Addis, T., and MacKay, E. M., Degree of compensatory renal hypertrophy following unilateral nephrectomy; influence of protein intake. J. Exper. Med., 1938, 67, 515.

11. Walter, F., and Addis, T., Organ work and organ weight. J. Exper. Med., 1939, 69, 467.

12. Allen, R. B., Bollman, J. L., and Mann, F. C., Effect of resection of large fractions of renal substance; an experimental study. Arch. Path., 1935, 19, 174.

13. Welsh, C. A., Rosenthal, A., Duncan, M. T., and Taylor, H. C., Jr., The effects of testosterone propionate on renal function in the dog, as measured by the creatinine and diodrast clearance and diodrast Tm. Am. J. Physiol., 1942, 137, 338.

14. Korenchevsky, V., and Ross, M. A., Kidneys and sex hormones. Brit. M. J., 1940, 1, 645. 
15. Korenchevsky, V., Dennison, M., and Kohn-Speyer, A., Changes produced by testicular hormone in normal and castrated rats. Biochem, J., 1933, 27, 557.

16. Korenchevsky, V., Dennison, M., and Kohn-Speyer, A., The effect of testicular hormone on normal sexually mature rats; a method of biological assay. Biochem. J., 1933, 27, 1506.

17. Korenchevsky, V., Hall, K., and Burbank, R., The manifold effects of prolonged administration of sex hormones to female rats. Biochem. J., 1939, 33, 372.

18. Lattimer, J. K., Action of testosterone propionate upon the kidneys of rats, dogs and men. J. Urol., 1942, 48, 778.

19. Smith, H. W., Goldring, W., and Chasis, H., The wen measurement of the tubular excretory mass, effeca tive blood flow and filtration rate in the normal human kidney. J. Clin. Invest., 1938, 17, 263.

20. Smith, W. W., Finkelstein, N., and Smith, H. W., Renal excretion of hexitols (sorbitol, mannitol and dulcitol) and their derivatives (sorbitan, isomannide and sorbide) and of endogenous creatinine-like chromogen in dog and man. J. Biol. Chem., 1940, 135, 231.

21. Welsh, C. A., Wellen, I., and Taylor, H. C., Jr., The filtration rate, effective renal blood flow, tubular excretory mass and phenol red clearance in normal pregnancy. . J. Clin. Invest., 1942, 21, 57.

22. Goldring, W., Chasis, H., Ranges, H. A., and Smith, H. W., Relations of effective renal blood flow and glomerular filtration to tubular excretory mass in normal man. J. Clin. Invest., 1940, 19, 739.

23. Smith, H. W., Lectures on the Kidney. William Henry Welch Lectures, Waverly Press, Baltimore, 1943.

24. Graef, I., Medial hypertrophy of renal arteries in pregnancy. Am. J. Path., 1943, 19, 121.

25. Wellen, I., Welsh, C. A., and Taylor, H. C., Jr., The filtration rate, effective renal blood flow, tubular excretory mass and phenol red clearance in specific toxemia of pregnancy. J. Clin. Invest., 1942, $21,63$.

26. Goldring, W., Chasis, H., Ranges, H. A., and Smith, H. W., Effective renal blood flow in subjects with essential hypertension. J. Clin. Invest., 1941, 20, 637. 